\title{
Sistem Penyewaan Mobil Berbasis Web (Studi Kasus Sastro Rent Car)
}

\author{
Nurul Lubna Mufidah ${ }^{1^{*}}$, M. Subchan Mauludin ${ }^{2}$ \\ ${ }^{1,2}$ Jurusan TEKNIK INFORMATIKA, Fakultas TEKNIK, Universitas Wahid Hasyim \\ Jl. Menoreh Tengah X/22, Sampangan, Semarang 50236 \\ *Email: nurullubna7@gmail.com
}

\begin{abstract}
Abstrak
Rental mobil merupakan salah satu usaha yang bergerak dibidang jasa yang dapat membantu masyarakat ketika memerlukan jasa persewaan mobil atau kendaraan dalam berbagai keperluan pribadi dan keperluan perusahaan. Ditinjau dari permasalahan yang terjadi yaitu tentang bagaimana cara calon customer agar lebih mudah untuk meminjam mobil tanpa harus ke lokasi penyewaan mobil langsung, maka penulis disini merancang dan mengimplementasikan sebuah sistem informasi penyewaan mobil berbasis website. Dengan website ini penyewa dapat menyewa mobil sesuai dengan keinginannya dengan mudah tanpa harus bertemu langsung ke tempat penyewaan mobil terlebih dahulu. Sistem ini dibuat menggunakan metode waterfall dengan PHP dan didukung oleh database MySQl untuk mengolah basis datanya. Hasil dari penelitian ini yaitu sebuah sistem informasi penyewaan mobil berbasis website (studi kasus Sastro Rent Car). Website ini merupakan website rental mobil yang menyewakan beberapa jenis mobil dan menyediakan jasa sopir. Pembuatan website ini menampilkan informasi tentang spesifikasi mobil yang akan disewakan terdiri dari harga sewa mobil, spesifikasi mobil dan merk mobil.
\end{abstract}

Kata kunci: MySql, PHP, Sistem Informasi, waterfall, Website

\section{PENDAHULUAN}

\subsection{Latar Belakang}

Perkembangan teknologi saat ini sangat cepat, khususnya dibidang teknologi informasi. Perkembangan teknologi informasi saat ini sangat mendukung dalam perkembangan sektor-sektor lainnya, seperti dalam dunia bisnis. Seperti contoh dalam perbisnisan persewaan mobil, persaingan antar persewaan mobil sekarang semakin ketat oleh sebab itu dibutuhkan suatu strategi pemasaran yang handal.

Rental mobil adalah salah satu usaha yang bergerak dibidang jasa yang dapat membantu masyarakat ketika memerlukan jasa persewaan mobil atau kendaraan dalam berbagai keperluan pribadi dan keperluan perusahaan. Sastro Rent Car merupakan suatu rental mobil yang beridir pada tahun 2016 terletak di Jl. Lamongan Barat IX, Sampangan, Kecamatan Gajahmungkur, Kota Semarang. Sastro Rent Car menyediakan pelayanan berupa rental mobil.

Dalam proses promosi perusahaan telah melakukan berbagai cara yaitu dengan saling memberi informasi melalui satu konsumen ke konsumen lainnya dan pemasangan iklan, ternyata cara tersebut kurang efektif karena perusahaan tidak dapat memberikan informasi tentang mobil-mobil yang akan disewakan secara lengkap dan detail sehingga konsumen kurang mendapatkan informasi yang lengkap dan akurat mengenai mobil-mobil yang akan disewakan oleh Sastro Rent Car.

Seiring berjalannya waktu semakin banyak permintaan dari pelanggan, sehingga berdampak pada proses pengolahan data transaksi. Data transaksi yang masuk semakin banyak dan cenderung akurat, juga lambat

dalam proses pengolahannya. Semua dikarenakan pada saat pemesanan mobil di Sastro Rent Car masih dilakukan dengan cara mencatat identitas penyewa dan mencatat jenis mobil yang akan disewa oleh penyewa di buku sewa. Hal tersebut mengakibatkan seringnya terjadi kehilangan data transaksi yang dibutuhkan. Penyusunan laporan transaksi penyewa bagi pemilik Sastro Rent Car menjadi tidak tepat waktu, karena data transaksi penyewaan yang tidak terdokumentasi dengan baik dan terstruktur.

Berdasarkan kondisi tersebut dibutuhkan sebuah sistem yang dapat membantu pengelolaan data khususnya transaksi 
penyewaan mobil yang ada pada Sastro Rent Car. Sistem tersebut selain digunakan untuk mengelola data mobil yang disewakan, data penyewa, juga untuk menghasilkan laporan transaksi penyewaan mobil.

Berdasarkan uraian dari latar belakang tersebut maka penulis melakukan penelitian dengan judul "Sistem Informasi Penyewaan Mobil Berbasis Web (Studi Kasus Sastro Rent Car)". Penelitian ini bertujuan untuk membangun suatu sistem penyewaan mobil yang mempermudah bagi penyewa untuk mengecek keadaan dan harga mobil. Selain itu dengan berbasiskan web maka informasi data dapat diakses kapan saja.

\subsection{Rumusan Masalah}

Rumusan masalah dalam penelitian ini yaitu Bagaimana merancang bangun sistem informasi penyewaan mobil berbasis web yang sesuai untuk Sastro Rent Car ?

\subsection{Batasan Masalah}

Berdasarkan rumusan masalah sebelumnya dan agar penelitian menjadi lebih fokus maka penulis membuat suatu batasan masalah yaitu :

1. Sistem mengelola dan menampilkan data mobil yang tersedia.

2. Sistem ini menghasilkan laporan transaksi penyewaan mobil.

3. Sistem informasi ini dapat diakses oleh pemilik rental dan calon penyewa mobil.

4. Sistem informasi ini hanya sampai pada tahap pengujian alpha.

\subsection{Tujuan Penelitian}

Berdasarkan rumusan masalah pada penelitian ini sehingga tujuan dari penelitian ini yaitu:

1. Merancang bangun sistem informasi penyewaan mobil berbasis web yang dapat memudahkan penyedia jasa rental dalam mengolah data.

2. Menghasilkan sistem informasi penyewaan mobil yang dapat memudahkan calon konsumen saat akan menyewa mobil.

\subsection{Manfaat Penelitian}

Manfaat yang diperoleh dari penelitian ini antara lain :

1. Bagi penulis
Menambah wawasan dan pengetahuan dalam mengembangkan sistem informasi penyewaan mobil.

2. Bagi Sastro Rent Car

Untuk menghasilkan suatu sistem penyewaan mobil yang menggunakan media web atau internet yang dapat membantu proses pemesanan menjadi lebih mudah dan praktis.

3. Bagi Akademik

Sebagai salah satu referensi sistem dalam rangka pengembangan penelitian selanjutnya.

\section{TINJAUAN PUSTAKA}

Sebelumnya telah ada penelitian yang membahas tentang sistem informasi penyewaan mobil, yaitu yang dilakukan oleh Hadi Zakaria (2017) yang berjudul "Perancangan Aplikasi Penjualan Dan Penyewaan Mobil Berbasis Web Menggunakan Model Waterfall Pada Cv. Dhiyara Anugrah". Menyampaikan bahwa aplikasi penyewaan mobil berbasis web yang menggunakan bahasa pemrograman PHP dan MySQL sebagai databasenya. Hasil yang dicapai dalam perancangan aplikasi penjualan dan penyewaan mobil berbasis web ini adalah pengolahan dan penyimpanan data yang lebih baik dan efesien, dengan adanya pelayanan transaksi penjualan dan penyewaan mobil secara terkomputerisasi yang tepat dan akurat untuk menunjang kinerja para karyawan CV Dhiyara Anugrah.

Hasil penelitian yang dilakukan oleh Yohanes S.B (2012) yang berjudul "Sistem Informasi Penyewaan Mobil Berbasis Web Di Rental Hafa Transport". Menyampaikan bahwa aplikasi penyewaan mobil ini akan lebih mempermudah calon konsumen untuk melihat mobil yang akan disewa dan mempermudah pembayaran melalui website.

Penulis akan menggunakan metode pengembangan sistem yaitu metod waterfall yang dimulai dari tahap perencanaan, analisi, perancangan, implementasi, testing dan pemeliharaan. Sedangkan alat bantu yang digunakan dalam pembangunan ini menggunakan UML (Unified Modeling Language) karena pada pengembangan sistem ini penulis akan menggunakan berbasis objek. Perbedaan dengan penelitian sebelumnya yaitu pada penelitian yang dikerjakan penulis yaitu merancangbangun sebuah sistem penyewaan mobil berbasis web menggunakan PHP MySql 
yang memudahkan pada saat pembuatan sistem dan sudah menggunakan teknologi responsive web.

\subsection{Landasan Teori}

\subsubsection{Rental Mobil}

Sewa atau rental menurut kamus besar bahsa Indonesia Departemen Pendidikan dan Kebudayaan Republik Indonesia, 2001 adalah pemakaian sesuatu dengan membayar uang sewa, uang yang dibayarkan karena memakai atau meminjamkan sesuatu, yang boleh dipakai dengan membayar uang dengan uang. Sedangkan pengertian penyewaan adalah proses, cara, pembuatan menyewa atau menyewakan. Yang dimaksud dengan sewa, yaitu balas jasa atas sewa ruang-ruangan dalam keadaan kosong yang dapat ditagih dimuka pada awal pemakaian mobil atau dibalakang, sesuai kontrak pemakaian

\subsubsection{Unified Modeling Language (UML)}

Unified Modeling Language (UML) merupakan alat bantu, bahasa pemodelan yang dapat digunakan untuk rancang bangun berorientsi-objek. UML dapat digunakan untuk spesifikasi, visualisasi dan dokumentasi sistem pada fase pengembangan. Walaupun banyak alat bantu pemodelan berorientasi-objek lain, UML dapat dikatakan merupakan alat bantu standar dalam bahasa pemodelan. Hal ini terbukti dengan diterimanya UML sebagai standar oleh Object Management Group (OMG), konsorsium terbesar di bidang bisnisobjek, sehingga Unified Modeling Language (UML) banyak diadopsi dan digunakan oleh banyak produsen perangkat lunak (Indrajani, 2011).

\subsubsection{ERD (Entity Relationship Diagram)}

Entity Relationship Diagram (ERD) adalah model yang dapat digunakan untuk memberikan pengertian mengenai data yang akan digunakan oleh suatu perusahaan. Dalam perancangan basisdata, entity relationship adalah pendekatan top-down dimana perancangan dimulai dengan mengidentifikasi data penting yang disebut entitas dan hubungan antara data yang harus dipresentasikan ke dalam model (Connolly dan Begg, 2015).

\subsubsection{Metode Waterfall}

Metode air terjun atau yang sering disebut metode waterfall sering dinamakan siklus hidup klasik (classic life cycle), dimana hal ini menggambarkan pendekatan yang sistematis dan juga berurutan pada pengembangan perangkat lunak, dimulai dengan spesifikasi kebutuhan pengguna lalu berlanjut melalui tahapan-tahapan perencanaan (planning), permodelan (modeling), konstruksi (construction), serta penyerahan sistem ke para pelanggan/pengguna (deployment), yang diakhiri dengan dukungan pada perangkat lunak lengkap yang dihasilkan (Pressman, 2012).

\subsubsection{Black Box Testing}

Menurut Rosa dan Shalahuddin (2011), black box testing (pengujian kotak hitam) yaitu menguji perangkat lunak dari segi spesifikasi fungsional tanpa menguji desain dan kode program. Pengujian dimaksud untuk mengetahui apakah fungsi-fungsi, masukan, dan keluaran dari perangkat lunak sesuai dengan spesifikasi yang dibutuhkan.

\section{METODE PENELITIAN}

\subsection{Bahan dan Materi}

Pada penelitian yang dilakukan oleh penulis dengan mengangkat tema "Sistem Informasi Penyewaan Mobil Berbasis Web (Studi Kasus Sastro Rent Car)", dalam pengembangan sistemnya penulis menggunakan bahasa pemrograman PHP sebagai back end atau server side dari sistem.

Untuk tampilan sistem yang lebih menarik penulis menggunakan beberapa bahasa pemrograman seperti HTML 5, CSS3, Jquery, Javascript. Untuk mempermudah dan mempercepat proses pembuatan halaman antarmuka pengguna atau user interface penulis menggunakan Bootsrap yaitu framework dari CSS yang sudah terintegerasi dengan HTML dan Javascript yang sudah siap pakai.

\subsection{Alat dan Bahan}

a. Hardware

1. Handphone

Handphone yang digunakan untuk tethering hotspot ke laptop dengan internet 
yang mempunyai koneksifitas 2G/3G/4G dengan merk Realme $\mathrm{C} 2$.

2. Flashdisk

Flashdisk yang digunakan yaitu Toshiba Flashdisk dengan kapasitas penyimpanan $8 \mathrm{~Gb}$ yang digunakan untuk mentransfer data jika diperlukan.

3. Komputer/laptop

Komputer yang digunakan dalam penelitian ini adalah Notebook Dell inspiron 11 yang memiliki spesifikasi sebagai berikut :

Ukuran Layar : 11.6" HD (1366 X 768)

Anti-Glare LED-Blacklit Display

Grafis : Intel HD Graphics

Processor : Intel Celeron N3060 (2MB

Chace, $1.60 \mathrm{GHz}$ up to $2.16 \mathrm{GHz}$ )

RAM : 2GB DDR3L 1600MHz

Storage $: 500 \mathrm{~GB}$.

b. Software

1. Platform yang digunakan dalam penelitian ini adalah Php versi 5.6.16

2. GUI yang digunakan adalah Sublime Text versi 3.0.

3. Pemodelan OOP UML Modeling yang digunakan adalah StarUML.

4. Webserver yang digunakan adalah XAMPP versi 5.6.25.

5. Browser Chrome.

\subsection{Metode pengumpulan data}

a. Metode Observasi

Pengumpulan data yang dilakukan dengan melihat dan meniliti secara langsung proses arus informasi baik informasi masuk maupun keluar yang dilakukan di Sastro Rent Car , sehingga sistem yang dihasilkan akan sessuai dengan kebutuhan dan menghasilkan laporan yang dapat dipertanggung jawabkan.

b) Wawancara

Pengumpulan data yang dilakukan menggunakan metode wawancara langsung dengan pemilik Sastro Rent Car sehingga data yang dihasilkan lebih terjamin keakuratannya.

c) Studi Kasus

Metode pengumpulan data yang diperoleh dari buku, jurnal, skripsi maupun internet sebagai referensi penulis.

\subsection{Metode Pengembangan Perangkat Lunak}

Dalam pemecahan masalah, penulis berpedoman pada rekayasa perangkat lunak. Untuk mempermudah proses analisis dan perancangan, penulis menggunakan metode Sistem Development Life Cycle (SDLC) atau biasa disebut dengan metode waterfall. Tahap tahap pengembangan perangkat lunak metode waterfall menurut pressman dapat dilihat pada gambar 1

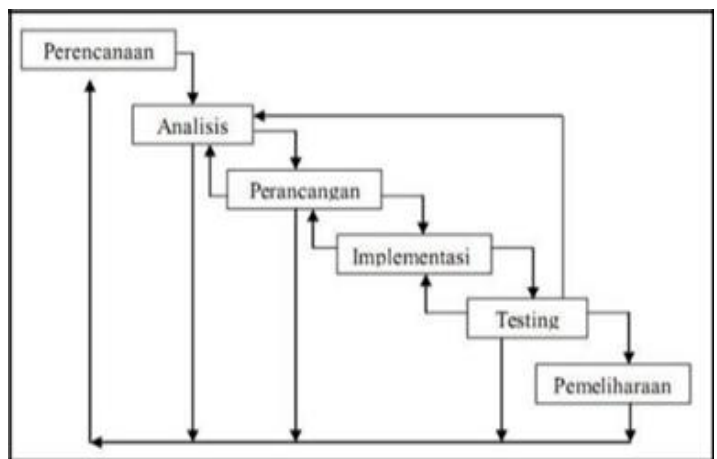

\section{Gambar 1. Model Waterfall}

\section{Requirement Analisis}

Tahap ini adalah analisa sitem yang berjalan dengan menggunakan flowmap untuk mengetahui gambaran umum pada sistem yang sedang berjalan. Pada tahap ini penulis melakukan wawancara kepada pemilik penyewaan mobil. Mencari informasi tentang data penyewaan mobil agar mendapatkan data yang valid yang nantinya akan dimasukkan kedalam website penyewaan mobil ini.

\section{System Design}

Desain perangkat lunak adalah proses multi langkah yang fokus pada desain pembuatan program perangkat lunak termasuk struktur data, arsitektur perangkat lunak, representasi antarmuka dan prosedur pengkodean. Desain dan pembuatan aplikasi berkonsentrasi pada bagaimana sistem dibangun untuk memenuhi kebutuhan pada fase analisis, membangun perangkat lunak untuk mendukung sistem meliputi pemodelan proses menggunakan UML, pemodelan data dengan menggunakan ERD, desain user interface input maupun output sistem informasi penyewaan mobil.

\section{Implementation}

Dalam tahap ini penulis memulai memasukan kode program (coding) ke dalam computer. Proses ini merupakan proses yang 
membutuhkan waktu cukup lama karena dalam proses pemrograman penulis membutuhkan kemampuan dan penguasasn program yang baik untuk membuat sistem penyewaan mobil tersebut. Script yang digunakan yaitu PHP MySql

4. Verification

Pada tahap ini penulis memastikan bahwa program yang dibuatnya terbebas dari kesalahan atau error, baik itu kesalahan dari sistem maupun dari user yang menggunakannya. Penulis mencoba memasukkan semua data yang ada pada sistem yang telah dibuat oleh penulis, jika terjadi kesalahan penulis akan memcoba mencari dimana kesalahanya dan membenarkan kode program yang mengalami kesalahan tersebut. Metode pengujiannya menggunakan blackbox dan hanya sampai pada tahap alpha.

\section{Maintenance}

Pada tahap pemeliharaan ini, penulis akan melakukan penyesuaian apabila perangkat lunak mengalami perubahan seperti perubahan yang diakibatkan kemampuannya kurang maksimal. Misalnya perangkat keras yang digunakan berubah ataupun sistem operasi yang berubah. Khusus untuk tahap pemeliharaan, tidak dilakukan karena tahap pembangunan perangkat lunak hanya akan sampai tahap pengujian.

\section{ANALISIS DAN PERANCANGAN}

\subsection{Analisis}

Kondisi Pengolahan data penyewaan mobil yang sedang berjalan di Sastro Rent Car masih menerapkan system manual yaitu masih menggunakan system pencatatan dengan menggunakan buku. Sehingga menimbulkan terjadinya penumpukan data yang berdampak pada sulitnyamendapatkan informasi penyewaan yang runtut, sehingga bias terjadi adanya kehilangan data pada buku. Keuntungan adanya system informasi pengolahan data penyewaan mobil berbasis web yang dirancang untuk Sastro Rent Car akan memberikan kemajuan pada tahap pencatatan data dan kemudahan calon customer untuk megecek jenis, harga dan stok mobil mana saja yang tersedia. Proses akan berjalan lebih cepat, informasi pun dapat mengalir tanpa hambatan,pengolahan data dan pembuatan laporan akan lebih mudah dilakukan dengan program yang mudah dioperasikan

\subsection{Perancangan}

\section{Pemodelan proses}

Pemodelan proses sistem menggunakan UML yang digunakan untuk merancang setiap proses yang akan dilakukan dalam pembuatan sistem penyewaan mobil.

\section{1) Use case diagram}

Pada gambar 2 dan gambar 3 merupakan diagram use case yang akan mempermudah dalam memahami peran dari aktor dalam menggunakan sistem yang akan dibuat oleh penulis.

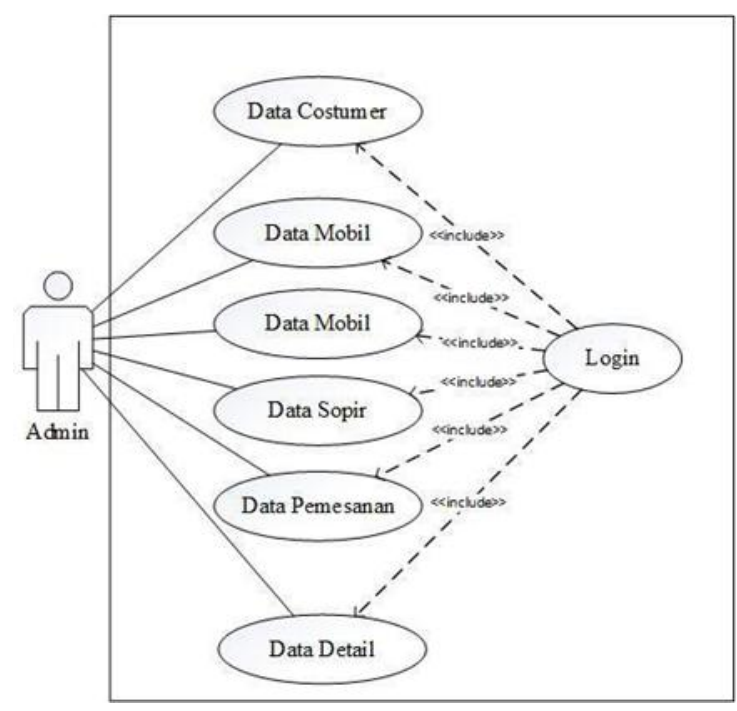

Gambar 2. Use Case Diagram Admin

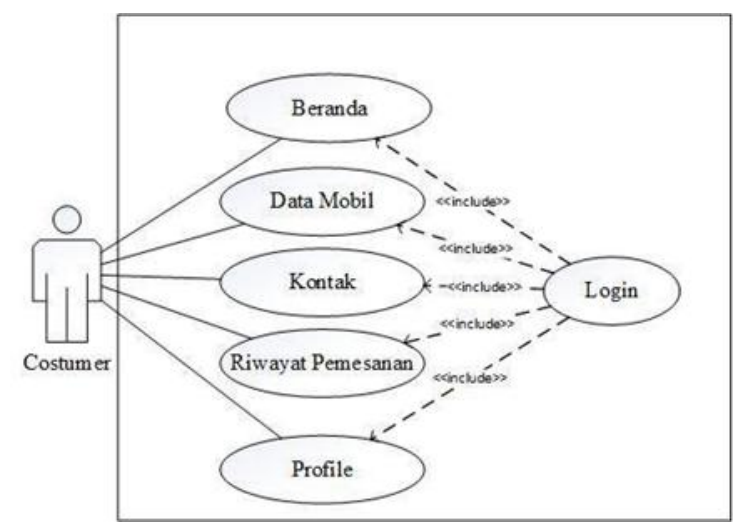

Gambar 3. Use case diagram Customer

\section{Pemodelan proses}

Pemodelan data pada electronic commerce sebagai media promosi berbasis web meliputi gambaran entity relationship diagram, perancangan tabel-tabel yang dibutuhkan basis data, dan membuat relasi antar tabel. 
1) Entity relationship diagram

Entity relationship diagram memberikan gambaran dan relasi-relasi yang ada didalamnya.

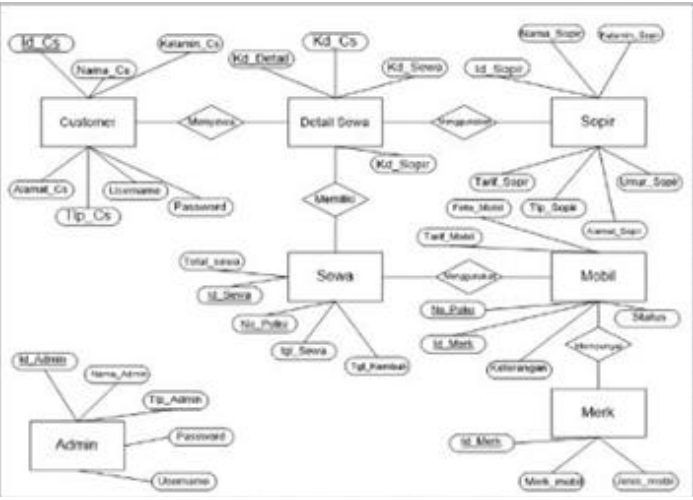

Gambar 4. Entity Relationship Diagram

\section{HASIL DAN PEMBAHASAN}

5.1 Implementasi Interface

1. Tampilan Halaman Awal

Implementasi halaman awal website berisi dari beberapa menu, seperti dapat dilihat pada gambar 5 .

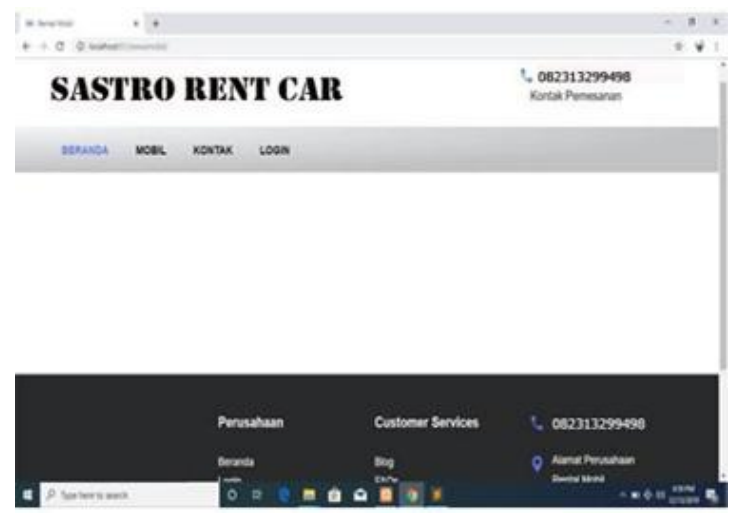

\section{Gambar 5. Tampilan Halaman Awal}

Halaman awal ini merupakan halaman yang pertama kali dapat dilihat oleh user saat mengakses website ini.

2. Tampilan Halaman Beranda

Pada tampilan ini merupakan halaman yang bertuliskan selamat datang kepada user saat mengakses website ini. Seperti dapat dilihat pada gambar 6 .

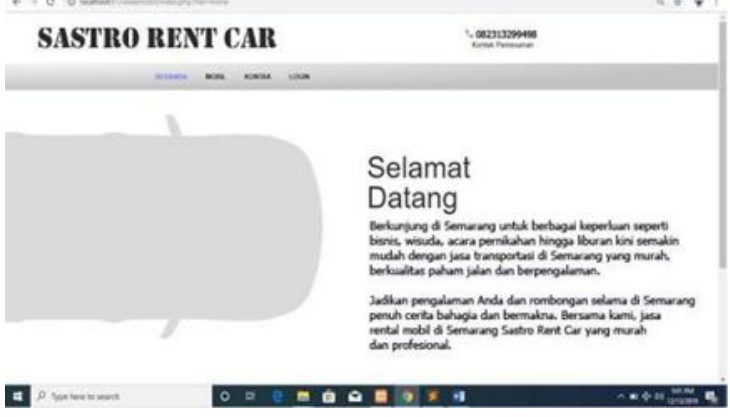

Gambar 6. Halaman Menu Beranda

3. Tampilan Halaman Menu Mobil

Pada halaman ini berisi informasi tentang mobil dan harga sewa mobil yang dapat dilihat user saat membuka website ini. Seperti terlihat pada gambar 7

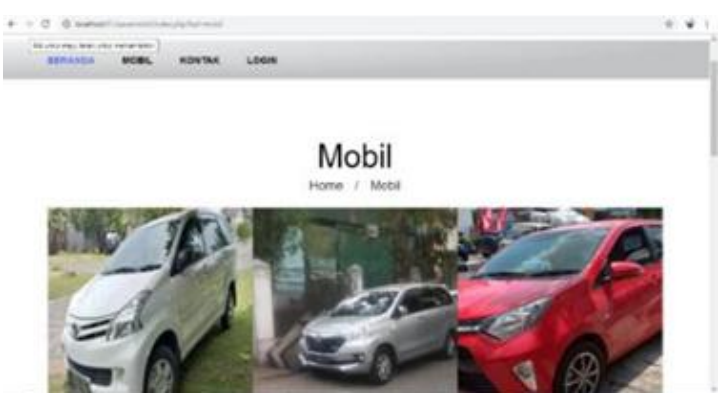

Gambar 7. Halaman Menu Mobil

4. Tampilan Halaman Menu Kontak

Pada halaman ini berisi kontak nomor yang dapat dihubungi dalam website ini. Seperti terlihat pada gambar 8 .

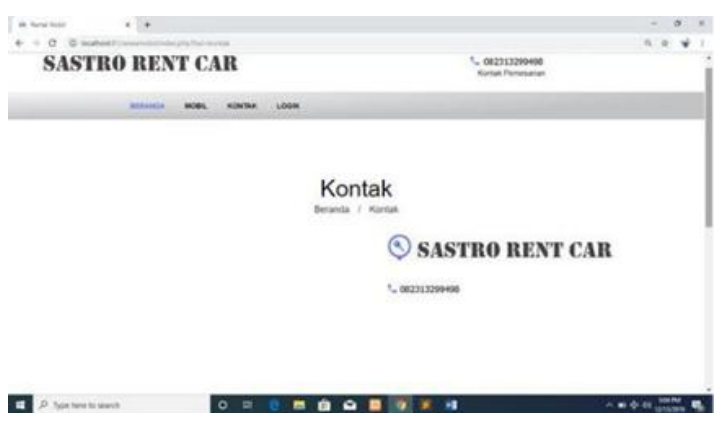

Gambar 8. Halaman Menu Kontak

5. Tampilan Halaman Menu Login User

Pada halaman ini user bisa melakukan pendaftaran login ke website penyewaan mobil ini agar bisa melakukan penyewaan mobil nantinya. Seperti terlihat pada gambar 9 . 

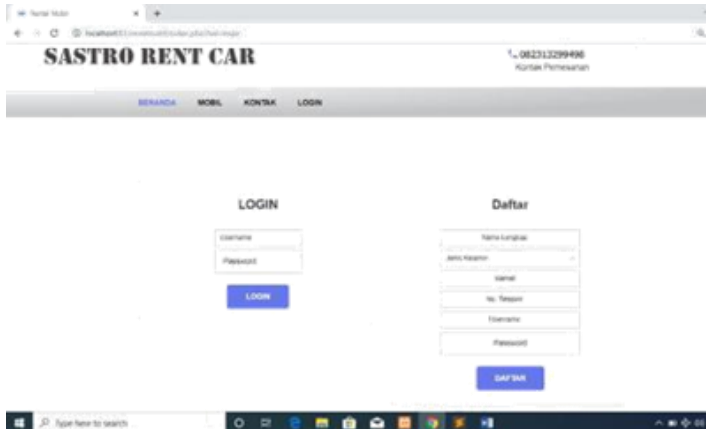

\section{Gambar 9. Halaman Menu Daftar}

Pada halaman menu login ini, user harus memasukkan beberapa biodata diri untuk mendaftarkan akun

6. Halaman Profil User

Pada halaman ini terdapat keterangan profil user yang seperti terlihat pada gambar 10 .

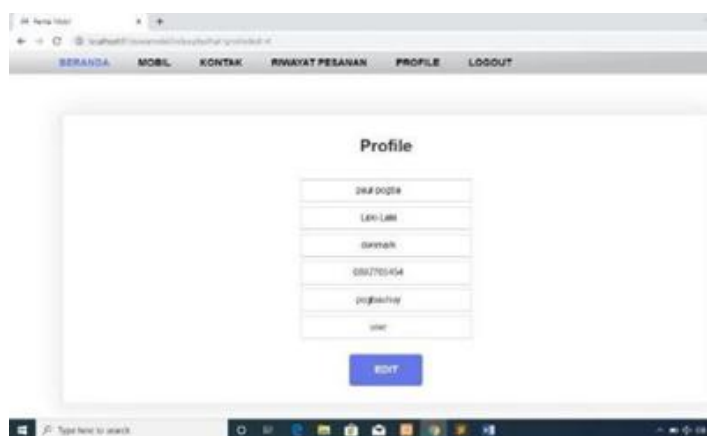

Gambar 10. Halaman Profil User

7. Halaman Menu Login admin

Pada halaman ini admin harus memasukkan username dan password untuk melakukan login ke halaman selanjutnya.

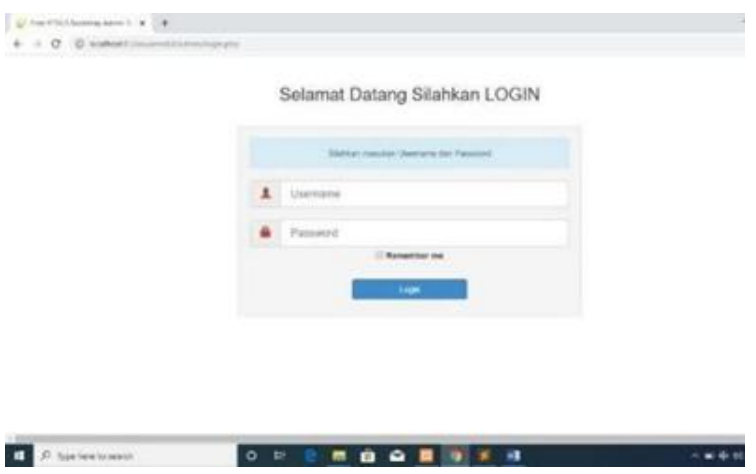

Gambar 11. Halaman Menu Login admin
8. Halaman Home Admin

Pada halaman ini merupakan halaman awal setelah admin berhasil login. Seperti terlihat pada gambar 12 .

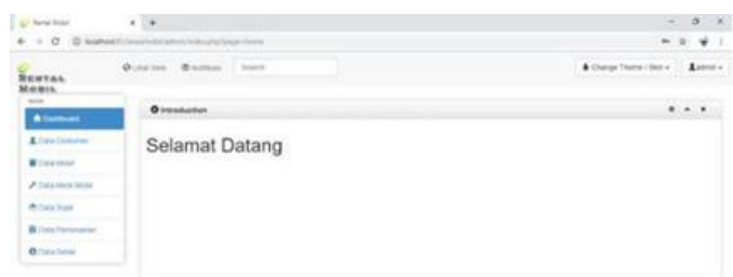

口.

\section{Gambar 12. Halaman Home Admin}

9. Halaman Menu Data Customer

Pada halaman menu ini terdapat keterangan siapa saja user yang login ke website ini. Seperti terlihat pada gambar 13.

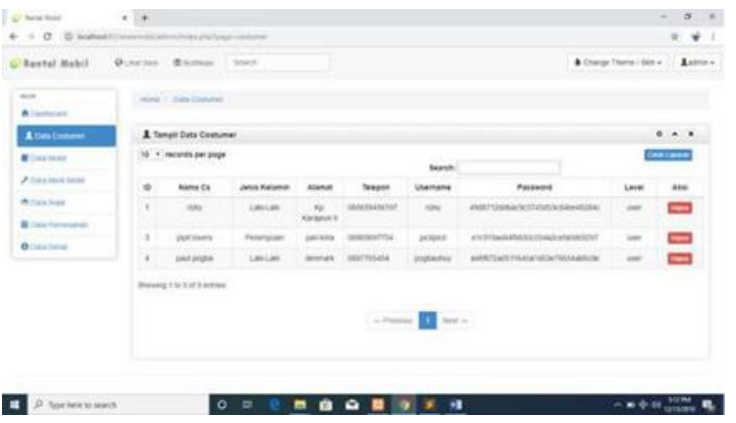

\section{Gambar 13. Halaman Menu Data Customer}

10. Halaman Menu Data Mobil

Pada halaman ini terdapat keterangan plat kendaraan, nama, harga dan keterangan mobil mana saja yang tersedia atau yang tidak tersedia. Seperti terlihat pada Gambar 14.

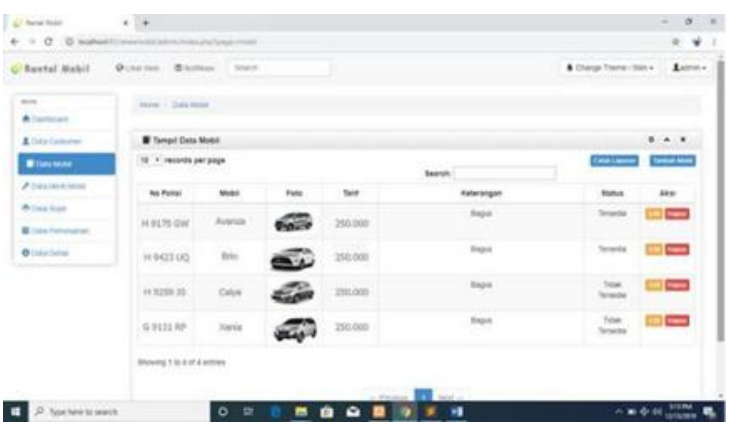

Gambar 14. Halaman Menu Data Mobil. 
11. Halaman Data Merk Mobil

Pada halaman ini terdapat keterangan tentang jenis dan merk mobil, seperti terlihat pada gambar 15 .

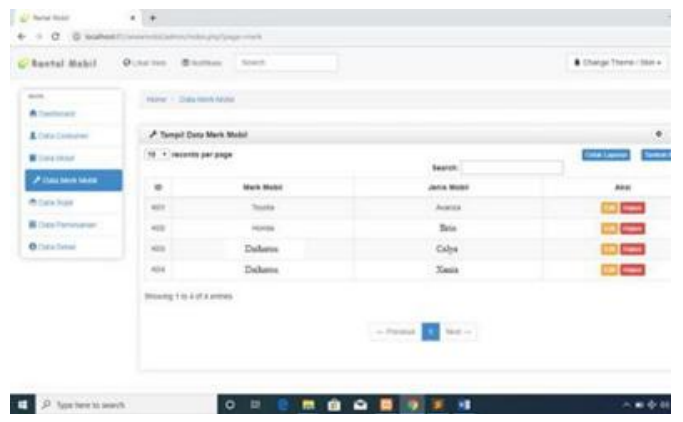

Gambar 15. Halaman Data Merk Mobil.

12. Halaman Menu Data Sopir

Pada halaman ini terdapat keterangan tentang nama dan identitas lainnya mengenai sopir yang ada di penyewaan monil ini. Seperti terlihat pada gambar 16 .

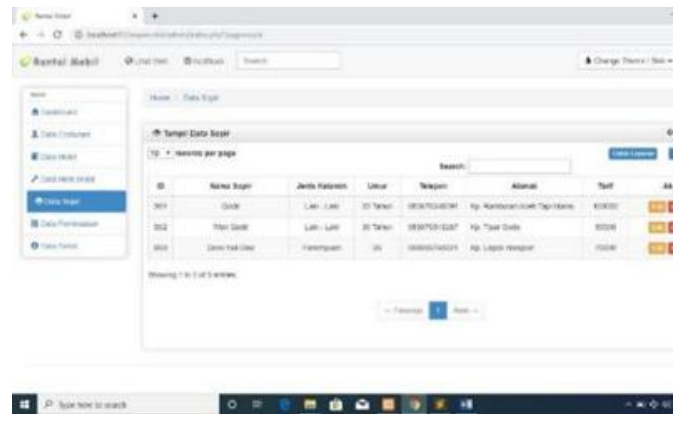

Gambar 16. Halaman Menu Data Sopir

13. Halaman Menu Data Pemesanan Pada halaman dibawah ini terdapat

keterangan mobil apa saja yang sedang disewa oleh user berikut keterangan tarif dan tanggal penyewaan. Seperti terlihat pada gambar 17.

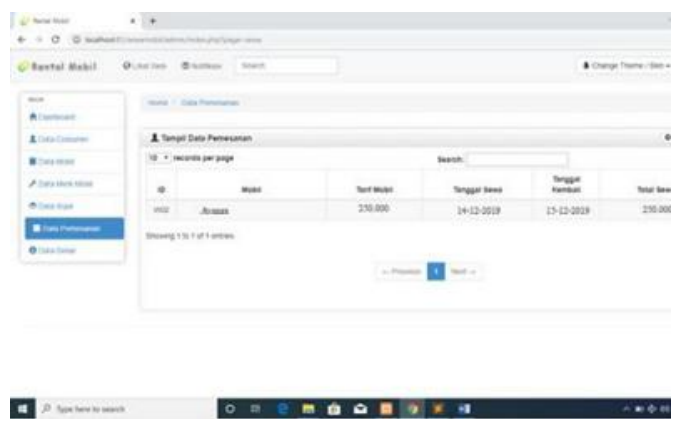

Gambar 17. Halaman Data Pemesanan
14. Halaman cetak laporan

Pada halaman dibawah ini terdapat halaman cetak laporan dari laporan rekapitulasi customer, laporan sopir, laporan mobil, dan laporan customer.

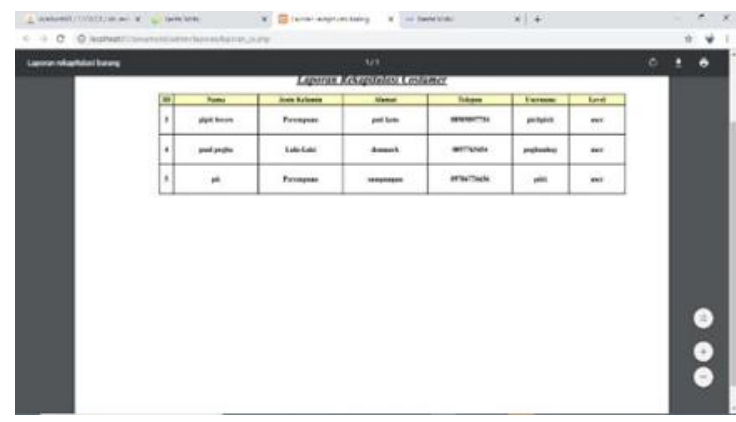

Gambar 18. Laporan Rekapitulasi Customer

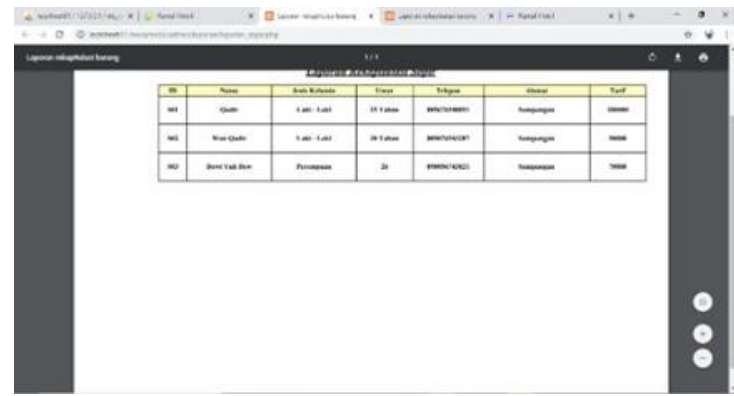

Gambar 19. Laporan Sopir

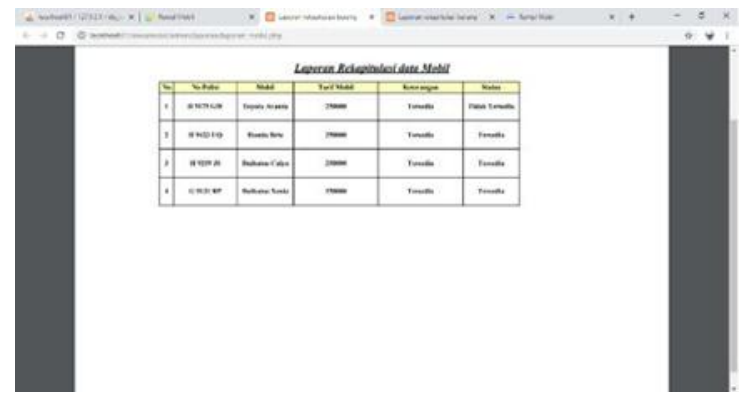

Gambar 20. Laporan Mobil

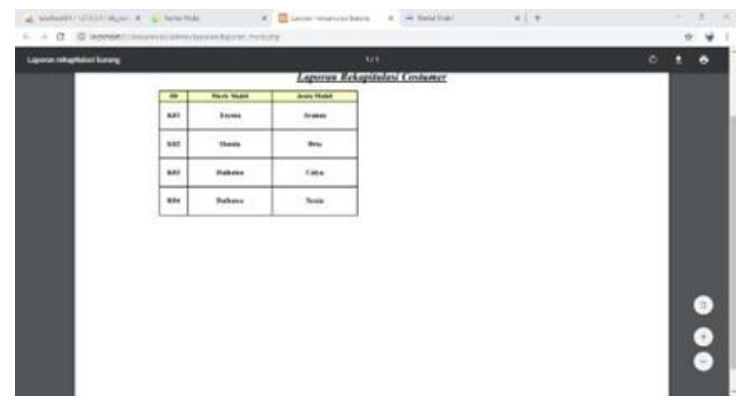

Gambar 21. Laporan Customer 
15. Halaman Proses Sewa

Pada gambar dibawah ini akan dijelaskan tentang proses pemesanan sewa mobil.

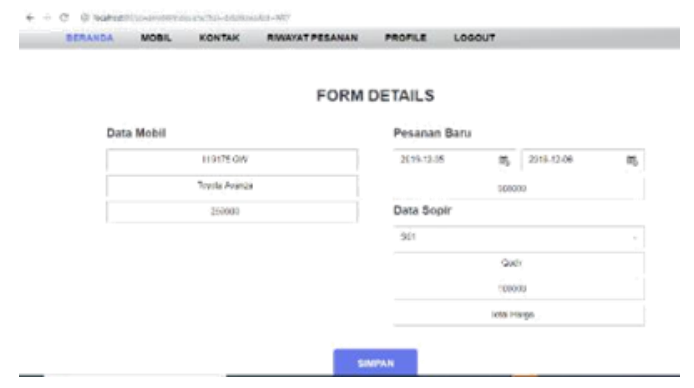

Gambar 22. Form Details

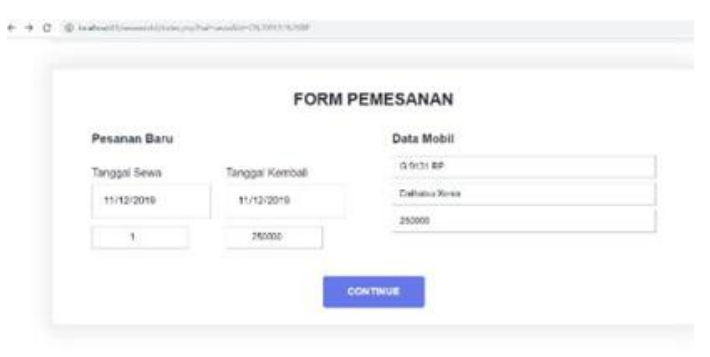

Gambar 23. Form pemesanan

\section{KESIMPULAN DAN SARAN}

6.1. Kesimpulan

Dari hasil pembahasan yang terdapat pada bab - bab sebelumnya, maka dapat ditarik kesimpulan sebagai berikut:

1. Sistem Informasi Penyewaan mobil pada

Sastro Rent Car Semarang berhasil dibangun dengan menggunakan Php MySql yang mempunyai banyak fitur dalam mempermudah dan mempercepat proses pengkodean baik dari segi mesin atau dari segi tampilan user interface.

2. Sistem yang dibuat siap untuk diimplementasikan pada Sastro Rent Car Semarang.

\subsection{Saran}

Terdapat beberapa saran dan masukkan untuk pengembangan lebih lanjut dari sistem yang sudah ada agar memberikan hasil penelitian yang lebih baik.

Berikut beberapa saran dan masukkan untuk menunjang kesempurnaan sistem yang telah dikembangkan:
1. Sistem perlu dilengkapi fasilitas chat online untuk memudahkan pelanggan menghubungi admin Sastro Rent Car.

2. Sistem ini dapat dikembangkan untuk melakukan perpanjangan waktu sewa secara online.

\section{DAFTAR PUSTAKA}

Connolly, Thomas dan Carolyn Begg. 2015. Database Systems: A Practical Approach to Design, implementation and management. Sixth Edition. Boston: Pearson Education.

Hadi, Zakaria, 2017. Perancangan Aplikasi Penjualan Dan Penyewaan Mobil Berbasis Web Menggunakan Model Waterfall Pada Cv. Dhiyara Anugrah. Fakultas Teknik. Universitas Pamulang.

Indrajani., 2011, Perancangan Basis Data Dalam All in 1, Elex Media Komputindo, Jakarta.

Kamus, Besar, Bahasa, Indonesia. 2001. Pengertian Sewa-Menyewa. Departemen Pendidikan dan Kebudayaan Republik Indonesia.

Pressman, Roger, S. 2012. Rekayasa Perangkat Lunak. Pendekatan Praktisi. Edisi 7. Yogyakarta : Andi

Rosa, A. S., Shalahuddin, M. 2011. Modul Pembelajaran Rekayasa Perangkat Lunak Terstruktur dan Berorientasi Objek. Bandung : Modula

Yohanes, S,B., 2012. Sistem Persewaan Mobil Berbasis Web Di Rental Hafa Transport, Sistem Informasi Universitas Dian Nuswantoro 